http:/www.journals.zu.edu.eg/journalDisplay.aspx?Journalld=1\&queryType=Master

\title{
ROLE OF BENTONITE ON POTASSIUM FERTILIZER EFFICIENCY IN RELATION TO ENHANCE GROWTH AND YIELD OF POTATO
}

\author{
Ramdan A. Mohamed ${ }^{1}$, M.A. Abd El-Rehem ${ }^{2}$ and A.M. Ibrahim² \\ 1. Hort. Res. Inst. Agric. Res. Cent. Giza, Egypt \\ 2. Soils, Water and Environ. Res. Inst., Agric. Res. Cent. Giza, Egypt
}

Received: 10/04/2017 ; Accepted: 01/06/2017

\begin{abstract}
Two field experiments were conducted at Ali Mubarak Horticultural Experiment Station, Behera Governorate, Egypt in split plot design during two successive seasons 2014/2015 and 2015/2016 to evaluate the effect of two types of bentonite (black and brown) and varied levels of Kfertilizer i.e., 0, 50, 75 and 100\% of the recommended dose (100 kg fad. $\left.{ }^{-1}\right)$, on some vegetative and yield parameters of potato plants and also their effect on some sandy soil properties. The results indicated significant increase for bentonite types on each of EC, CEC, OM, WHC, FC and available NPK of sandy soil. Meanwhile, their effect on soil $\mathrm{pH}$ was non significant. The difference between the influences of the two types of bentonite were non significant for all studied parameters of the soil except CEC, WHC and FC where the difference was significant. The effect of K-levels on the forenamed properties was non significant except available K. The interaction effect was non significant for all soil parameters except available $\mathrm{N}$ and $\mathrm{K}$. Application of 15 ton/fad., from either black or brown bentonite or K-fertilizer levels solely as compared with the control, increased significantly the growth and yield parameters of potato plants. The black bentonite was superior to the brown bentonite on yield parameters. The highest effect was obtained when the soil treated with bentonite and K-fertilizer together. Foliage content of NPK affected significantly by applying 15 ton/fad., of bentonite but the differences in the influence between the two types were non significant. The tuber content of NPK, starch and protein affected significantly with the two types of bentonite but the black was better than the brown in this concern. Increasing K-fertilizer increased significantly foliage and tuber content of NPK while the interaction effect of bentonite $+\mathrm{K}$ - fertilizer was better than each alone.
\end{abstract}

Key word: Sandy soil, types of bentonite, K- fertilizer and potato productivity.

\section{INTRODUCTION}

Bentonite as a natural deposite was evaluated as sandy soil conditioner by several investigators (Lotfy and El-Hady, 1984). They found that these deposits have high clay content and high percentage of semectite minerals, as well as, high surface area and CEC values. Iskander et al. (2011) found that bentonite could raise the storage capacities of soil for water and fertilizer. In addition, bentonite reduced soil fixation for phosphorus and potassium. Jena and Kabi (2012) reported that application of bentonite as soil amendment possible to increase number and

* Corresponding author: Tel. : +201007051595

E-mail address: agriramadan@yahoo.com size of potato tuber. Tawfiq (2009) reported that, bentonite can decrease decomposition rate of organic substance and improve humiliation coefficient, so it can raise the quality and the quantity of organic matter, improve the sandy soil fertility, growth yield and chemical composition of plants.

Potato (Solanum tuberosum L.) is a crop of major significance in human nutrition, ranking in food production, after wheat, corn and rice. It was selected due to its economic importance in Egypt. Fertilization is an important factor in potato production technology to achieve optimum yield of tubers. Potato is regarded as 
an indicator crop for soil K- availability due its high K-requirement (Roberts and Mc Dole, 1985).

Moreover, K- enhances water uptake and root permeability and acts as a guard cell controller, beside its role in increasing water use efficiency (Zekri and Obreza, 2009).

The objective of this work is to study the effect of two types of bentonite on potassium fertilizer efficiency in relation to enhance growth and yield of potato and some soil properties of sandy soil.

\section{MATERIALS AND METHODS}

During two successive seasons (2014/2015 and 2015/2016) two field experiments were conducted in Ali Mubarak Agriculture Research Station at Behera Governorate, Egypt on potato plants (Sponta cultivar) to study the effect of two types of bentonite (black and brown) on some chemical and physical properties of sandy soil and also on some vegetative and yield parameters of potato plants. The soil was treated with 15 ton/fad., from each one of the used bentonite. Analysis of the experimental soil and the used bentonite were presented in Tables (1 and 2). The used bentonite was supplied by International Company for Mining and Investment (ICMI). The field experiments were arranged as a split plot design with four replicates. The main plot factor was bentonite types, while Kfertilizer rates were allotted in the sub plots. Bentonite mixed with the surface layer $(0-20$ $\mathrm{cm}$ ) for all experiment plots. The full amount of calcium phosphate $\left(16 \% \mathrm{P}_{2} \mathrm{O}_{5}\right)$ at rate of 75 $\mathrm{kg} / \mathrm{fad}$., were added at the time of final soil preparation. The potato tubers were sown under drip irrigation with $50 \mathrm{~cm}$ width, with $10.5 \mathrm{~cm}$ length and $25 \mathrm{~cm}$ apart on side of a ridge. Each experimental plot consists of $10 \mathrm{~m}^{2}$. Tuber was planted at $10 \mathrm{~cm}$ depth and $25 \mathrm{~cm}$ apart within the row.

Ammonium sulphate $(20.5 \% \mathrm{~N})$ at rates of $200 \mathrm{~kg} \mathrm{~N} /$ fad., and K-fertilizer (potassium sulphate $48 \% \mathrm{~K}_{2} \mathrm{O}$ ) treatments were added as percentage $(0,50,75$ and $100 \%)$ of the recommended dose (100 $\mathrm{kg} \mathrm{K}_{2} \mathrm{O} / \mathrm{fad}$.) through the drip irrigation system.

After 90 days from planting date, six plants from each sub experimental plot were randomly taken for recording the following data for vegetative growth characteristics i.e. plant height $(\mathrm{cm})$, number of branches/plant, fresh and dry weights of foliage/plant (g).

At harvesting stage, tuber yield characteristics which include tuber number and tuber yield (ton/fad.) were recorded. Samples of tubers were taken at harvesting and dried at $70^{\circ} \mathrm{C}$ for determine starch, protein and NPK content. Total nitrogen percentage was determined using modified micro Kjaldahl, phosphors was determined using colorimetric method using spectrophotometer according to Cottenie et al. (1982), while potassium percentage was measured using phlame photometer as described by Chapman and Pratt (1982). Starch and protein were determined according the method described by AOAC (1990).

Chemical analysis of the experimental soil foliage and tubers were conducted on the combined sample taken after harvesting of two seasons.

\section{Statistical Analysis}

The collected data were subjected to an analysis of variance using the statistical analysis method described by Snedecor and Cochran (1990). Differences among means within the samples were tested using Duncan's multiplerange test at the $5 \%$ probability level.

\section{RESULTS AND DISCUSSION}

\section{Effect of Bentonite Types and K-Fertilizer Level on Some Sandy Soil Properties}

Results in Table 3 clarify that the values of soluble salts $\left(\mathrm{EC} \mathrm{dSm}^{-1}\right)$ increased significantly due to application of the studied types of bentonite compared with control. The differences among the two types of bentonite in this concern were non significant. Also, results reveal that there are non significant differences in EC values by using different levels of K-fertilizer. Concerning to the soil $\mathrm{pH}$ values, results in Table 3 show that there is no significant differences in soil $\mathrm{pH}$ values as a result of bentonite or K- application. The values of cation exchange capacity (CEC) in Tables 1 and 2 reveal that this parameter in bentonite was exceed than that of soil by about two times. As the importance of this parameter and its effect 
Table 1. Some physical and chemical properties of the experimental soil

\begin{tabular}{|c|c|c|}
\hline Soil characteristics & $\begin{array}{l}\text { First season } \\
(2014-2015) \\
\end{array}$ & $\begin{array}{c}\text { Second season } \\
(2015-2016)\end{array}$ \\
\hline \multicolumn{3}{|l|}{$\begin{array}{l}\text { Practical size distribution } \\
\text {. }\end{array}$} \\
\hline Coarse sand (\%) & 66.50 & 67.20 \\
\hline Fine sand (\%) & 22.20 & 21.30 \\
\hline Silt (\%) & 2.20 & 2.40 \\
\hline Clay (\%) & 9.20 & 9.10 \\
\hline Textural class & Sandy & Sandy \\
\hline O.M (\%) & 0.22 & 0.25 \\
\hline $\mathrm{CaCO}_{3} \quad(\%)$ & 1.70 & 1.60 \\
\hline Field capacity & 11.80 & 11.70 \\
\hline W.H.C. & 19.8 & 20.12 \\
\hline $\mathrm{pH}(1: 2.5)$ soil water suspension & 7.75 & 7.81 \\
\hline C.E.C.(Cmol /kg soil) & 4.30 & 4.50 \\
\hline EC $\left(\mathrm{dSm}^{-1}\right)$ (soil paste extract) & 0.43 & 0.45 \\
\hline \multicolumn{3}{|l|}{ Soluble cations (mmole /l) } \\
\hline $\mathrm{Ca}^{++}$ & 1.20 & 1.32 \\
\hline $\mathrm{Mg}^{++}$ & 1.70 & 1.80 \\
\hline $\mathrm{Na}^{+}$ & 1.28 & 1.30 \\
\hline $\mathrm{K}^{+}$ & 0.17 & 0.19 \\
\hline \multicolumn{3}{|l|}{ Soluble Anions (mmol/l) } \\
\hline $\mathrm{HCO}_{3}^{-}$ & 2.30 & 2.20 \\
\hline $\mathrm{Cl}^{-}$ & 1.41 & 1.71 \\
\hline $\mathrm{SO}_{4}^{--}$ & 0.64 & 0.64 \\
\hline \multicolumn{3}{|l|}{ Available nutrients (mg/kg soil) } \\
\hline $\mathrm{N}$ & 20.10 & 21.35 \\
\hline $\mathrm{P}$ & 8.80 & 9.00 \\
\hline $\mathrm{K}$ & 40.10 & 41.00 \\
\hline
\end{tabular}

Table 2. Chemical analysis of the used bentonite

\begin{tabular}{|c|c|c|c|c|c|c|c|c|c|c|c|c|c|}
\hline $\begin{array}{c}\text { Bentonite } \\
\text { type }\end{array}$ & $\mathrm{SiO}_{3}$ & $\mathbf{A l}_{2} \mathbf{O}_{3}$ & $\mathrm{FeO}_{3}$ & MgO & $\mathrm{CaO}$ & $\mathrm{Na}_{2} \mathrm{O}$ & $\mathbf{K}_{2} \mathbf{O}$ & $\mathrm{TiO}_{2}$ & $\mathrm{MnO}_{2}$ & $\begin{array}{c}\mathrm{EC} \\
\mathrm{dSm}^{-1}\end{array}$ & pH & $\begin{array}{c}\text { CEC } \\
\text { (C. } \\
\text { mole) }\end{array}$ & $\begin{array}{c}\text { Water } \\
\text { Holding } \\
\text { capacity }\end{array}$ \\
\hline Black & 56.10 & 15.50 & 2.99 & 1.17 & 7.18 & 1.07 & 1.21 & 0.56 & 0.06 & 10.00 & 7.48 & 74 & 125 \\
\hline Brown & 60.30 & 19.30 & 1.70 & 0.40 & 2.70 & 0.08 & 0.20 & 0.60 & 0.10 & 12.00 & 7.61 & 66 & 115 \\
\hline
\end{tabular}


Table 3. Effect of bentonite types and varied levels of $\mathrm{K}$-fertilizer on some properties of the studied soil (combined of two seasons)

\begin{tabular}{|c|c|c|c|c|c|c|c|c|c|}
\hline \multirow[t]{2}{*}{ Treatment } & \multirow[t]{2}{*}{$\begin{array}{c}E C \\
\left(\mathrm{dSm}^{-1}\right)\end{array}$} & \multirow[t]{2}{*}{$\begin{array}{c}\text { pH } \\
(1: 2.5)\end{array}$} & \multirow[t]{2}{*}{$\begin{array}{c}\text { C.E.C } \\
\mathrm{mol} / \mathrm{kg} \\
\text { soil }\end{array}$} & \multirow[t]{2}{*}{$\begin{array}{c}\text { Organic } \\
\text { matter } \\
(\%)\end{array}$} & \multirow{2}{*}{$\begin{array}{c}\text { Water } \\
\text { holding } \\
\text { capacity } \\
\text { (WHC) }\end{array}$} & \multirow[t]{2}{*}{$\begin{array}{c}\text { Field } \\
\text { capacity } \\
\text { (FC) }\end{array}$} & \multicolumn{3}{|c|}{$\begin{array}{c}\text { Available } \\
\text { macronutrients } \\
\text { (mg/kg) }\end{array}$} \\
\hline & & & & & & & $\mathbf{N}$ & $\mathbf{P}$ & $\mathbf{K}$ \\
\hline \multicolumn{10}{|c|}{ Bentonite type } \\
\hline Control & 1.95 & 7.80 & 4.20 & 0.24 & 20.10 & 11.63 & 26.23 & 9.25 & 45.75 \\
\hline Black & 3.10 & 7.85 & 6.40 & 0.41 & 24.98 & 16.75 & 34.45 & 12.13 & 59.00 \\
\hline Brown & 3.20 & 7.90 & 5.70 & 0.38 & 22.23 & 13.48 & 34.03 & 11.55 & 58.03 \\
\hline LSD 5\% & 0.60 & NS & 0.51 & 0.02 & 1.30 & 1.10 & 3.10 & 0.90 & 5.10 \\
\hline \multicolumn{10}{|c|}{ K-fertilizer rate } \\
\hline $\mathbf{0}$ & 2.48 & 7.79 & 4.42 & 0.30 & 20.20 & 13.48 & 30.33 & 10.67 & 49.33 \\
\hline 50 & 2.83 & 7.81 & 4.45 & 0.29 & 20.20 & 13.93 & 31.00 & 10.93 & 52.62 \\
\hline 75 & 2.86 & 7.85 & 4.47 & 0.31 & 20.30 & 13.97 & 32.40 & 11.20 & 56.00 \\
\hline 100 & 2.93 & 7.86 & 4.50 & 0.31 & 20.50 & 14.00 & 32.47 & 11.20 & 58.33 \\
\hline LSD 5\% & NS & NS & NS & NS & NS & NS & NS & NS & 3.10 \\
\hline
\end{tabular}

on all soil properties, application of bentonite affected highly significant on this parameter in the studied soil. Application of 15 ton/fad., from black bentonite increased the values of CEC by $53.51 \%$ relative to control, where this increase reached to $35.71 \%$ for 15 ton/fad., of brown bentonite. Also, the obtained results clarify that there is no significant difference in the values of CEC due to the application of K-fertilizer. It is well known that the CEC is a good measure of soil ability to retain and supply nutrient to crops and in general indicated to soil fertility. CEC is higher in soil with high amounts of clay and OM content (Jones and Jacobsen, 2001). Other authors found that application of bentonite into sandy soil, significantly increased CEC of these soils, Croker et al. (2004), Satje and Nelson (2009), Yssad and Belkhodja (2007) and Churchman et al. (2012).

Organic matter (OM) values as shown in Table 3 indicated that application of 15 ton/fad., of black or brown bentonite increased significantly values of this parameter in the studied soil, where the effect of $\mathrm{K}$ - fertilizer application was non significant when applied without bentonite. This result may be due to the effect of bentonite minerals on roots distribution and growth of microorganisms in root zone. Also, bentonite increasing stabilization in soil and consequently increase OM in the soil. This result is in agreement with that reported by Janusz and Grzegorz (2013).

As a result of highness of water holding capacity (WHC) of the two bentonite types, Table 2 compared to the lowest of this parameter in the studied soil, application of black or brown bentonite caused significant increases in the values of this parameter (Table 3). Black bentonite was superior to the brown one. On the other hand, K- fertilizer application did not caused significant differences in WHC, $\mathrm{Qu}$ et al. (2008) reported that application of bentonite led to increase WHC and consequently improve water and nutrient supply to plant.

Concerning to the field capacity (FC) results in Table 3 indicated that application of bentonite either black or brown to sandy soil caused significant increases in the values of FC compared to the control. Application of 15 ton/fad., black bentonite increased FC of the experimental soil by $24.30 \%$ relative to control. This increase amounted to $10.60 \%$ in case of 
Table 4. Interaction effect of bentonite types and levels of K-fertilizer on some properties of the studies soil (combined of two studied seasons)

\begin{tabular}{|c|c|c|c|c|c|c|c|c|c|c|}
\hline \multicolumn{2}{|l|}{ Treatment } & \multirow{3}{*}{$\begin{array}{c}E C \\
\left(\mathrm{dSm}^{-1}\right)\end{array}$} & \multirow{3}{*}{$\begin{array}{c}\text { pH } \\
(1: 2.5)\end{array}$} & \multirow{3}{*}{$\begin{array}{c}\text { CEC } \\
\mathrm{mol} / \mathrm{kg} \\
\text { soil }\end{array}$} & \multirow{3}{*}{$\begin{array}{l}\text { OM } \\
\text { (\%) }\end{array}$} & \multirow[t]{3}{*}{ WHC } & \multirow[t]{3}{*}{ FC } & \multirow{2}{*}{\multicolumn{3}{|c|}{$\begin{array}{c}\text { Available } \\
\text { macronutrients } \\
(\mathrm{mg} / \mathrm{kg})\end{array}$}} \\
\hline \multirow{2}{*}{$\begin{array}{c}\text { Bentonite } \\
\text { type }\end{array}$} & \multirow{2}{*}{$\begin{array}{c}\text { Rates of K- } \\
\text { (kg/fad.) }\end{array}$} & & & & & & & & & \\
\hline & & & & & & & & $\mathbf{N}$ & $\mathbf{P}$ & $\mathbf{K}$ \\
\hline \multirow{4}{*}{ 0 } & $\mathbf{0}$ & 1.85 & 7.78 & 4.25 & 0.28 & 19.90 & 11.50 & 25.40 & 9.10 & 42.00 \\
\hline & 50 & 1.90 & 7.60 & 4.20 & 0.29 & 20.10 & 11.60 & 25.30 & 9.30 & 45.00 \\
\hline & 75 & 1.98 & 7.61 & 4.10 & 0.29 & 20.00 & 11.70 & 27.20 & 9.30 & 48.00 \\
\hline & 100 & 2.10 & 7.82 & 4.20 & 0.30 & 20.20 & 11.70 & 27.00 & 9.30 & 48.00 \\
\hline \multirow{4}{*}{ Black } & 0 & 3.10 & 7.90 & 6.40 & 0.41 & 24.50 & 16.80 & 33.10 & 11.80 & 52.00 \\
\hline & 50 & 3.20 & 7.90 & 6.40 & 0.42 & 24.40 & 16.70 & 34.20 & 12.10 & 58.00 \\
\hline & 75 & 3.20 & 7.90 & 6.50 & 0.42 & 24.60 & 16.70 & 35.10 & 12.40 & 61.00 \\
\hline & 100 & 3.30 & 7.90 & 6.50 & 0.40 & 26.60 & 16.80 & 35.50 & 12.40 & 64.00 \\
\hline \multirow{4}{*}{ Brown } & $\mathbf{0}$ & 3.30 & 7.85 & 5.80 & 0.38 & 22.20 & 13.40 & 32.00 & 11.10 & 53.00 \\
\hline & 50 & 3.40 & 7.80 & 5.75 & 0.38 & 22.10 & 13.50 & 33.50 & 11.40 & 54.00 \\
\hline & 75 & 3.40 & 7.85 & 5.80 & 0.38 & 22.30 & 13.50 & 34.90 & 11.60 & 59.00 \\
\hline & 100 & 3.40 & 7.90 & 5.80 & 0.39 & 22.3 & 13.50 & 34.90 & 11.90 & 63.00 \\
\hline LSD $5 \%$ & & 0.70 & NS & NS & NS & NS & NS & 2.10 & NS & 2.90 \\
\hline
\end{tabular}

brown one. Also, results reveal non significant effect of K- fertilizer treatments on FC values.

As for the availability of macronutrients $(\mathrm{N}$, $\mathrm{P}$ and $\mathrm{K}$ ) presented in Table 3, results revealed that application of 15 ton/fad., of black or brown bentonite increased significantly the values of available $\mathrm{N}, \mathrm{P}$ and $\mathrm{K}$ of the studied soil compared to control, without significant differences between the two types. The highest increases of available $\mathrm{N}, \mathrm{P}$ and $\mathrm{K}$ were realized by using 15 ton/fad., black bentonite (Table 3).

The different levels of $\mathrm{K}$ - fertilizer had no significant effect on available $\mathrm{N}$ or $\mathrm{P}$, where its effect on available $\mathrm{K}$ was significant.

The interaction effect of bentonite and Kfertilizer on soil properties, data in Table 4 indicated that the effect of two types of bentonite with different levels of K-fertilizer on EC, pH, CEC, OM, WHC, FC and available P of soil was non significant where this effect was significant on $\mathrm{N}$ and $\mathrm{K}$ content.
Briefly, it could be stated that application of 15 ton/fad., of black or brown bentonite on surface layers of sandy soil results in significant positive effect on the values of EC, CEC, OM, and WHC, FC and N, P and $\mathrm{K}$ but their effect on soil $\mathrm{pH}$ values was non significant as affected by the black bentonite which was superior to brown bentonite.

Results also, reveal that the effect of varied $\mathrm{K}$ - levels on the forenamed parameters was non significant except for available $\mathrm{N}$ and $\mathrm{K}$ it was significant.

\section{Impact of Bentonite Types and K-Fertilizer Levels on Some Vegetative Parameters of Potato}

Results presented in Table 5 revealed that application of 15 ton/fad., from black or brown bentonite to sandy soil resulted in significant increases in the values of vegetative growth of potato i.e. plant height; number of branches/ plant; fresh weight and dry weight/plant for both studied seasons compared with control without 
Table 5. Vegetative growth parameters of potato plants as affected by bentonite types and Kfertilizer levels

\begin{tabular}{ccccccccc}
\hline & \multicolumn{9}{c}{ First season } & & \multicolumn{5}{c}{ Second season } \\
\cline { 2 - 9 } Treatment & $\begin{array}{c}\text { Plant } \\
\text { height } \\
\text { (cm) }\end{array}$ & $\begin{array}{c}\text { Number of } \\
\text { branches }\end{array}$ & $\begin{array}{c}\text { Fresh } \\
\text { weight } \\
\text { g/plant }\end{array}$ & $\begin{array}{c}\text { Dry } \\
\text { weight } \\
\text { g/plant }\end{array}$ & $\begin{array}{c}\text { Plant } \\
\text { height } \\
\text { (cm) }\end{array}$ & $\begin{array}{c}\text { Number of } \\
\text { branches }\end{array}$ & $\begin{array}{c}\text { Fresh } \\
\text { weight } \\
\text { g/plant }\end{array}$ & $\begin{array}{c}\text { Dry } \\
\text { weight } \\
\text { g/plant }\end{array}$ \\
\hline $\begin{array}{c}\text { Bentonite type } \\
\text { Control }\end{array}$ & 53.70 & 3.87 & 412.36 & 50.80 & 51.04 & 3.61 & 405.59 & 49.44 \\
Black & 66.95 & 4.83 & 476.70 & 59.35 & 64.89 & 5.36 & 484.50 & 61.40 \\
Brown & 61.77 & 5.60 & 462.83 & 56.71 & 58.81 & 4.71 & 459.36 & 58.60 \\
LSD 5\% & 6.40 & 0.90 & 20.20 & 4.10 & 6.50 & 0.72 & 26.10 & 3.90 \\
K-fertilizer rate & & & & & & & & \\
$\mathbf{0}$ & 54.97 & 3.95 & 397.50 & 50.36 & 53.40 & 3.57 & 377.66 & 50.76 \\
$\mathbf{5 0}$ & 57.81 & 4.54 & 428.15 & 53.59 & 55.63 & 4.29 & 420.23 & 54.86 \\
$\mathbf{7 5}$ & 62.31 & 4.98 & 468.21 & 57.95 & 59.67 & 4.87 & 460.41 & 58.30 \\
$\mathbf{1 0 0}$ & 67.10 & 5.41 & 508.78 & 60.61 & 64.12 & 5.22 & 494.01 & 62.08 \\
LSD 5\% & 3.20 & 0.31 & 20.10 & 2.2 & 2.10 & 0.31 & 20.20 & 3.10 \\
\hline
\end{tabular}

no significant between differencing the two types. These results are in good accordance with that found by Shaheen et al. (2013). This positive effect of bentonite may be attributed to its highness of cation exchange capacity (CEC) which reflected on its water holding capacity and nutrients retention which improve water and nutrients supply to plants (Ding et al., 2009; Qu et al., 2008).

Concerning to the effect of K-fertilizer, data also, showed significant difference in the vegetative growth of potato plants in the studied seasons among the different percentage used of the recommended dose of K-fertilizer $(100 \mathrm{~kg} /$ fad., $\mathrm{K}_{2} \mathrm{O}$ ). The highest and the lowest values of these parameters were obtained in the plants received $100 \%$ and zero of the recommended Kfertilizer, respectively.

Potassium plays crucial role in maintenance of tissue water relation, aids in photosynthesis, enhances $\mathrm{N}$-uptake and protein synthesis resulting in better foliage growth (Marschner, 1995). Also, Marton (2001) and Soha et al. (2001) observed increased foliage with $\mathrm{K}$ and $\mathrm{N}$ application.
As for to the interaction effect of bentonite and $\mathrm{K}$ - fertilizer on some vegetative parameters, Table 6 show that the highest values were realized when the plants received 15 ton/fad., brown bentonite $+100 \%$ of recommended Kfertilizer, without significant difference between this treatment and black bentonite $+100 \% \mathrm{~K}$ recommended K- fertilizer.

It can also show that the effect of application $100 \%$ of K-fertilizer without bentonite on the vegetative growth parameters nearly equal to the effect of applying 15 ton/fad., black bentonite + $50 \%$ of recommended $\mathrm{K}$ - fertilizer.

\section{Effect of Bentonite Types and K-Fertilizer Level on Some Yield Parameters of Potato}

Results presented in Table 7 indicated that application of 15 ton/fad., of brown or black bentonite caused significant increases in the values of the studied yield parameters (tuber number/plant, tuber yield/plant, weight of one tuber (g) and tuber yield (ton/fad.) compared with control. In the contrast with the vegetative parameters, the black bentonite was better than the brown one in this concern. This 
Zagazig J. Agric. Res., Vol. 44 No. (4) 2017

Table 6. Interaction effect of bentonite types and K-rates on some vegetative growth of potato plant

\begin{tabular}{|c|c|c|c|c|c|c|c|c|c|}
\hline \multirow[b]{2}{*}{$\begin{array}{l}\text { Bentonite } \\
\text { type }\end{array}$} & \multirow{2}{*}{$\begin{array}{l}\text { K rates } \\
\text { (kg/fad.) }\end{array}$} & \multicolumn{4}{|c|}{ First season } & \multicolumn{4}{|c|}{ Second season } \\
\hline & & $\begin{array}{c}\text { Plant } \\
\text { height } \\
\text { (cm) }\end{array}$ & $\begin{array}{c}\text { Number of } \\
\text { branches/ } \\
\text { plant }\end{array}$ & $\begin{array}{c}\text { Fresh } \\
\text { weight/ } \\
\text { plant }\end{array}$ & $\begin{array}{c}\text { Dry } \\
\text { weight/ } \\
\text { plant }\end{array}$ & $\begin{array}{l}\text { Plant } \\
\text { height } \\
\text { (cm) }\end{array}$ & $\begin{array}{c}\text { Number of } \\
\text { branches/ } \\
\text { plant }\end{array}$ & $\begin{array}{c}\text { Fresh } \\
\text { weight/ } \\
\text { plant }\end{array}$ & $\begin{array}{c}\text { Dry } \\
\text { weight// } \\
\text { plant }\end{array}$ \\
\hline \multirow{4}{*}{0} & $\mathbf{0}$ & 49.48 & 2.97 & 373.99 & 45.92 & 48.47 & 2.85 & 360.40 & 43.79 \\
\hline & 50 & 50.73 & 3.65 & 396.08 & 49.81 & 49.15 & 3.33 & 384.40 & 46.66 \\
\hline & 75 & 55.14 & 4.08 & 414.56 & 52.33 & 51.16 & 4.04 & 404.19 & 50.94 \\
\hline & 100 & 59.40 & 4.77 & 467.90 & 55.26 & 55.13 & 4.45 & 472.18 & 56.40 \\
\hline \multirow{4}{*}{$\begin{array}{l}\text { Black } 15 \\
\text { ton/fad. }\end{array}$} & $\mathbf{0}$ & 55.50 & 4.23 & 404.70 & 51.27 & 53.16 & 4.21 & 412.23 & 52.39 \\
\hline & 50 & 58.49 & 4.79 & 435.46 & 54.39 & 56.36 & 4.64 & 430.28 & 57.20 \\
\hline & 75 & 61.13 & 4.79 & 494.69 & 59.31 & 59.67 & 4.85 & 491.06 & 60.50 \\
\hline & 100 & 70.27 & 5.34 & 516.49 & 61.90 & 66.06 & 5.16 & 503.93 & 64.32 \\
\hline \multirow{4}{*}{$\begin{array}{l}\text { Brown } 15 \\
\text { ton/fad. }\end{array}$} & $\mathbf{0}$ & 59.80 & 4.67 & 413.83 & 58.91 & 53.90 & 4.55 & 420.91 & 56.12 \\
\hline & 50 & 64.21 & 5.16 & 452.90 & 56.56 & 61.37 & 5.10 & 440.18 & 59.20 \\
\hline & 75 & 70.66 & 5.90 & 494.68 & 62.23 & 68.19 & 5.73 & 484.29 & 64.32 \\
\hline & 100 & 73.11 & 6.11 & 544.93 & 64.68 & 71.10 & 5.80 & 505.91 & 66.12 \\
\hline LSD $5 \%$ & & 4.10 & 0.90 & 29.10 & 4.30 & 5.30 & 0.66 & 28.10 & 5.50 \\
\hline
\end{tabular}

Table 7. Tuber yield parameters of potato plants as effected by types of bentonite and levels of potassium fertilizer

\begin{tabular}{|c|c|c|c|c|c|c|c|c|}
\hline \multirow[b]{2}{*}{ Treatment } & \multicolumn{4}{|c|}{ First season } & \multicolumn{4}{|c|}{ Second season } \\
\hline & $\begin{array}{c}\text { No. of } \\
\text { tubers/ } \\
\text { plant }\end{array}$ & $\begin{array}{c}\text { Tuber } \\
\text { yield / } \\
\text { plant (g) }\end{array}$ & $\begin{array}{c}\text { Weight } \\
\text { of one } \\
\text { tuber (g) }\end{array}$ & $\begin{array}{c}\text { Tuber } \\
\text { yield } \\
\text { (ton/fad.) }\end{array}$ & $\begin{array}{c}\text { No. of } \\
\text { tubers/ } \\
\text { plant }\end{array}$ & $\begin{array}{c}\text { Tuber } \\
\text { yield/ } \\
\text { plant (g) }\end{array}$ & $\begin{array}{l}\text { Weight of } \\
\text { one tuber } \\
\text { (g) }\end{array}$ & $\begin{array}{c}\text { Tuber } \\
\text { yield } \\
\text { (ton/fad.) }\end{array}$ \\
\hline \multicolumn{9}{|l|}{ Bentonite } \\
\hline Control & 5.30 & 639.50 & 100.47 & 10.37 & 5.60 & 662.44 & 103.44 & 10.45 \\
\hline Brown & 6.30 & 667.488 & 106.35 & 11.61 & 6.39 & 710.33 & 109.00 & 11.43 \\
\hline Black & 6.70 & 709.70 & 109.33 & 12.60 & 6.80 & 739.32 & 114.69 & 12.56 \\
\hline LSD 5\% & 0.25 & 18.50 & 3.10 & 0.45 & 0.21 & 18.80 & 3.30 & 0.51 \\
\hline \multicolumn{9}{|c|}{ Potassium fertilizer } \\
\hline $\mathbf{0}$ & 5.20 & 450.35 & 95.59 & 8.33 & 5.47 & 515.97 & 99.38 & 8.44 \\
\hline 50 & 5.59 & 561.57 & 100.12 & 9.54 & 6.63 & 592.36 & 105.32 & 9.83 \\
\hline 75 & 6.91 & 763.64 & 110.12 & 12.98 & 6.92 & 796.89 & 115.21 & 12.82 \\
\hline 100 & 7.76 & 886.60 & 115.81 & 15.07 & 7.17 & 911.56 & 117.00 & 14.66 \\
\hline LSD 5\% & 0.30 & 20.10 & 6.10 & 1.10 & 0.31 & 26.10 & 6.30 & 1.20 \\
\hline
\end{tabular}


may be due to the obvious differences in CEC Also, Ding et al. (2009) and Shaheen et al. (2013) found that bentonite application as a soil conditioner caused increase in tuber yield over the control. They owing this positive effect of bentonite to its plasticity and negatively led to charges on its surfaces. These features make it capable to absorb large quantities of water and available nutrients. Also, the highest increases in yield parameters were recorded by applying 15 ton/fad., of black bentonite.

Concerning to the effect of K-fertilizer, data showed that increasing the percentage of $\mathrm{K}$ fertilizer was acompanied by successive increase in the values of yield parameters of potato plants. The differences between K-fertilizer doses in this concern were significant. The highest increases in tuber yield/fad., owing to Kfertilizer were recorded by using $100 \%$ of recommended dose. On the other hand, the lowest values were obtained under neither bentonite nor K-fertilizer addition. This result is in agreement with the findings of Umar and Mairu (2001) and Singh and Lai (2012) they found that the increase in potato tuber yield due to K-application was up to $290 \mathrm{~kg} / \mathrm{fad}$., the increase in total yield and the yield of large tubers due to K-fertilization may be owing to the stimulating effect of $\mathrm{K}$ on photosynthesis, phloem loading and translocation, as well as, synthesis of large organs contributing to the rapid bulking of the tubers (Singh, 1999).

Also, Upodhaya and Sharma (1987) and Imas and Bansal (2002) reported that rapid bulking potato varieties producing large size tubers responded more to $\mathrm{K}$ than the varieties with small size tubers as application of $\mathrm{K}$ - is known to increase the tuber size.

Concerning to the interaction effect of bentonite and K-fertilizer on some yield parameters, data in Table 8 indicate that the highest value of yield parameters were obtained in the plots treated with 15 ton/fad., black bentonite $+100 \% \mathrm{~K}$ of recommended dose of Kfertilizer, where the lowest values recoded in the control which neither received bentonite nor Kfertilizer. It can be notice that the averages of tuber weight as the more important parameter of quality affective significantly by application any of the two types of the studied bentonite as well as, by increasing K-fertilizer either they adding individually or together. The increases in the tuber yield over the control reached to 15.96 , 14.30 and $77.54 \%$ where plots treated by 15 ton/ fad., black bentonite, 15 ton/fad., brown bentonite or $100 \%$ recommended dose of K-fertilizer, each applied alone, respectively, in the first year.

The increases in the tuber yield in second year were $19.10,13.90$ and 56.48 at the same order in the first year. When the plots received 15 ton/fad., black bentonite $+100 \%$ of recommended dose of K- fertilizer or 15 ton/ fad., brown bentonite $+100 \%$ recommended dose of $\mathrm{K}$ - fertilizer in first year the increases reached to 109.14 and 97.35 , respectively. In the second year the increases reached to 122.10 and $107.96 \%$ compared to control in the same order. These results indicated that application of bentonite with K-fertilizer was superior to using each alone.

\section{Foliage Content of N, P and K (Combined Data of two Seasons)}

Data in Table 9 refer to exist significant influence of foliage content of $\mathrm{N}, \mathrm{P}$ and $\mathrm{K}$ compared to the control, where the differences between the two types of bentonite on these parameters were non significant. As for the effect of K- fertilizer levels, the obtained data reveal that increase $\mathrm{K}$ dose led to significant increases in values of $\mathrm{N}$ content of foliage but the differences between dose (75 and $100 \%$ ) were not significant. Values of $\mathrm{P}$ content of foliage as affected by $\mathrm{K}$ - fertilizer, the present data refer to taken this parameter the same trend of $\mathrm{N}$ values.

As for foliage content of $\mathrm{K}$, it can observe gradual increase by increasing K-fertilizer dose; these increases were significant compared to the control. The differences between K-fertilizer doses on this parameter were significant.

\section{Interaction Effect of Two Bentonite Types + Varied K Levels on Foliage Content of $\mathbf{N}$, $P$ and $K$}

Data of foliage content of N, P and $\mathrm{K}$ as recorded in Table 10 indicated that interaction affect between the two types of bentonite and four levels of K-fertilizer was significant for foliage content of $\mathrm{N}, \mathrm{P}$ and $\mathrm{K}$. The highest values were recorded when the plants treated with 
Zagazig J. Agric. Res., Vol. 44 No. (4) 2017

Table 8. Interaction effect of bentonite types and K-rates on some yield parameters of potato yield

\begin{tabular}{|c|c|c|c|c|c|c|c|c|c|}
\hline \multirow{2}{*}{$\begin{array}{l}\text { Bentonite } \\
\text { type }\end{array}$} & \multirow{2}{*}{$\begin{array}{c}\text { K rates } \\
\text { (kg/fad.) }\end{array}$} & \multicolumn{4}{|c|}{ First season } & \multicolumn{4}{|c|}{ Second season } \\
\hline & & $\begin{array}{c}\text { No. of } \\
\text { tubers/ } \\
\text { plant }\end{array}$ & $\begin{array}{c}\text { Tuber } \\
\text { yield / } \\
\text { plant (g) }\end{array}$ & $\begin{array}{c}\text { Average } \\
\text { tuber } \\
\text { weight }\end{array}$ & $\begin{array}{c}\text { Tuber } \\
\text { yield } \\
\text { ton/fad. }\end{array}$ & $\begin{array}{c}\text { No. of } \\
\text { tubers/ } \\
\text { plant }\end{array}$ & $\begin{array}{c}\text { Tuber } \\
\text { yield / } \\
\text { plant (g) }\end{array}$ & $\begin{array}{c}\text { Average } \\
\text { tuber } \\
\text { weight }\end{array}$ & $\begin{array}{c}\text { Tuber } \\
\text { yield } \\
\text { ton/fad. }\end{array}$ \\
\hline \multirow{4}{*}{0} & $\overline{0}$ & 4.89 & 445.26 & 91.06 & 7.57 & 4.94 & 462.50 & 93.59 & 7.56 \\
\hline & 50 & 5.73 & 558.50 & 96.80 & 8.35 & 5.81 & 563.89 & 97.18 & 9.80 \\
\hline & 75 & 6.92 & 704.46 & 101.76 & 11.97 & 6.92 & 755.14 & 108.94 & 11.84 \\
\hline & 100 & 7.53 & 849.45 & 112.72 & 13.44 & 7.62 & 870.21 & 114.26 & 12.30 \\
\hline \multirow{4}{*}{$\begin{array}{l}\text { Black } 15 \\
\text { ton/fad. }\end{array}$} & $\mathbf{0}$ & 5.16 & 516.60 & 99.65 & 8.78 & 5.26 & 551.23 & 104.72 & 9.37 \\
\hline & 50 & 5.54 & 564.30 & 101.91 & 9.59 & 5.56 & 621.13 & 112.13 & 10.59 \\
\hline & 75 & 6.98 & 824.99 & 118.20 & 14.02 & 6.43 & 836.70 & 120.91 & 14.22 \\
\hline & 100 & 7.77 & 932.64 & 119.88 & 15.85 & 7.62 & 946.10 & 120.96 & 16.80 \\
\hline \multirow{4}{*}{$\begin{array}{l}\text { Brown } 15 \\
\text { ton/fad. }\end{array}$} & $\mathbf{0}$ & 5.27 & 504.20 & 97.20 & 8.65 & 5.35 & 534.16 & 99.80 & 8.95 \\
\hline & 50 & 5.49 & 561.65 & 102.11 & 9.54 & 5.53 & 590.06 & 106.70 & 9.60 \\
\hline & 75 & 6.80 & 761.47 & 111.46 & 12.98 & 6.90 & 798.70 & 115.77 & 12.40 \\
\hline & 100 & 7.67 & 877.76 & 114.73 & 14.92 & 7.78 & 918.28 & 118.53 & 15.62 \\
\hline LSD 5\% & & 0.35 & 23.10 & 4.10 & 0.61 & 0.40 & 22.30 & 3.80 & 0.71 \\
\hline
\end{tabular}

Table 9. Effect of bentonite types and K-fertilizer levels on potato foliage content of $\mathbf{N}, \mathbf{P}$ and $\mathrm{K}$ (combined data of two seasons)

\begin{tabular}{cccc}
\hline Treatment & $\mathbf{N}$ & $\mathbf{P}$ & $\mathbf{K}$ \\
$\mathbf{( \% )}$ & $\mathbf{( \% )}$ & $\mathbf{( \% )}$ \\
\hline Bentonite types & & & \\
$\mathbf{0}$ & 2.38 & 0.35 & 1.75 \\
$\mathbf{1 5}$ ton/fed black & 3.00 & 0.53 & 2.15 \\
$\mathbf{1 5}$ ton/fed brawn & 2.99 & 0.44 & 2.14 \\
LSD 5\% & 0.37 & 0.047 & 0.25 \\
K- fertilizer levels & & & \\
$\mathbf{0}$ & 2.08 & & 1.46 \\
$\mathbf{5 0}$ & 2.70 & 0.39 & 1.80 \\
$\mathbf{7 5}$ & 3.10 & 0.42 & 2.20 \\
$\mathbf{1 0 0}$ & 3.23 & 0.44 & 0.28 \\
$\mathbf{L S D} 5 \%$ & 0.38 & 0.021 & \\
\hline
\end{tabular}


Table 10. Interaction effect of bentonite types and K-fertilizer levels on foliage content of $\mathbf{N}, \mathbf{P}$ and $K$ (combined data of two seasons)

\begin{tabular}{ccccc}
\hline Bentonite type & K-fertilizer (\%) & $\mathbf{N}$ & $\mathbf{P}$ & $\mathbf{K}$ \\
& & $\mathbf{( \% )}$ & $\mathbf{( \% )}$ & $\mathbf{( \% )}$ \\
\hline \multirow{2}{*}{$\mathbf{0}$} & $\mathbf{0}$ & 1.73 & 0.32 & 1.35 \\
& $\mathbf{5 0}$ & 2.35 & 0.34 & 1.65 \\
& $\mathbf{7 5}$ & 2.55 & 0.36 & 1.85 \\
& $\mathbf{1 0 0}$ & 2.75 & 0.38 & 2.15 \\
$\mathbf{1 5}$ ton/fad., black & $\mathbf{0}$ & 2.20 & 0.45 & 1.53 \\
& $\mathbf{5 0}$ & 3.00 & 0.47 & 2.00 \\
& $\mathbf{7 5}$ & 3.40 & 0.49 & 2.40 \\
$\mathbf{1 5}$ ton/fad., brown & $\mathbf{1 0 0}$ & 3.60 & 0.49 & 2.80 \\
& $\mathbf{0}$ & 2.25 & 0.41 & 1.50 \\
& $\mathbf{5 0}$ & 2.80 & 0.46 & 2.00 \\
LSD 5\% & $\mathbf{7 5}$ & 3.35 & 0.47 & 2.30 \\
\hline
\end{tabular}

15 ton/fad., black bentonite $+100 \%$ of recommended dose of $\mathrm{K}$ - fertilizer for $\mathrm{N}$ and $\mathrm{K}$ content while the plants treated with black or brown bentonite $+100 \%$ recommended dose of $\mathrm{K}$ - fertilizer gave the same values of $\mathrm{P}$ content.

\section{Some Chemical Constituents of Potato Tubers as Affected by Bentonite and K- Fertilizer}

Table 11 show the combined analysis of the two season's data for chemical composition of potato tubers i.e. starch, protein as well as $\mathrm{N}, \mathrm{P}$ and $\mathrm{K} \%$. Application of 15 ton/fed black or brown bentonite caused significant increases in starch, protein, $\mathrm{N}, \mathrm{P}$ and $\mathrm{K}$ content of tubers compared to the control. The differences between the two types of bentonite in this concern were non significant. As, for Kfertilizer application it can observe gradual increase in the value of starch, protein, $\mathrm{N}, \mathrm{P}$ and $\mathrm{K}$ of tubers associated with increasing level of K- fertilizer.

Interaction effect between bentonite and Kfertilizer on chemical composition of potato tuber (combined analysis of two seasons) values of starch, protein, $\mathrm{N}, \mathrm{P}$ and $\mathrm{K}$ in potato tuber (Table 12) increased significantly in case of application bentonite K-fertilizer levels. The highest increase of starch, protein, $\mathrm{N}$ and $\mathrm{K}$ contents were obtained by application of 15 to/fad., bentonite $+100 \%$ of recommended Kfertilizer without significant difference with application of 15 ton/fad., bentonite +75 of recommended dose of $\mathrm{K}$ - fertilizer.

There were non significant difference between interaction effect of black and brown with $\mathrm{K}$ - fertilizer on all chemical constitutes of potato tuber. The interaction effect in $\mathrm{P}$ contents was non significant. The obtained results are in good agreement with those reported by Shahzad et al. (2010), Mohammed and Mohammed (2012) and Shaheen et al. (2013).

\section{Conclusion}

The application of bentonite whether added solely or in combination of K-fertilizer had, a significantly positive effect on grown yield and chemical composition of potato plant grown in sandy soil. The highest increases were obtained by addition 15 ton/fad., bentonite combined with 
Zagazig J. Agric. Res., Vol. 44 No. (4) 2017

Table 11. Effect of bentonite type and K-fertilizer level on chemical composition of potato tuber (combined analysis of two seasons)

\begin{tabular}{cccccc}
\hline Treatment & $\begin{array}{c}\text { Starch } \\
\mathbf{( \% )}\end{array}$ & $\begin{array}{c}\text { Protein } \\
\mathbf{( \% )}\end{array}$ & $\begin{array}{c}\mathbf{N} \\
\mathbf{( \% )}\end{array}$ & $\begin{array}{c}\mathbf{P} \\
\mathbf{( \% )}\end{array}$ & $\begin{array}{c}\text { K } \\
\mathbf{( \% )}\end{array}$ \\
\hline Bentonite type & & & & & \\
Control & 67.88 & 9.50 & 1.55 & 0.39 & 1.35 \\
$\mathbf{1 5}$ ton/fed black & 72.97 & 12.45 & 1.99 & 0.46 & 2.17 \\
$\mathbf{1 5}$ ton/fed brown & 72.55 & 12.39 & 1.94 & 0.45 & 2.60 \\
$\quad$ LSD 5\% & 3.00 & 1.05 & 0.23 & 0.05 & 0.41 \\
K- Fertilizer level (\%) & & & & & \\
$\mathbf{0}$ & 67.90 & 10.28 & 1.64 & 0.43 & 1.61 \\
$\mathbf{5 0}$ & 70.50 & 11.64 & 1.83 & 0.48 & 2.07 \\
$\mathbf{7 5}$ & 72.80 & 11.95 & 1.96 & 0.49 & 2.18 \\
$\mathbf{1 0 0}$ & 73.29 & 12.25 & 1.99 & 0.50 & 2.20 \\
LSD 5\% & 2.00 & 1.20 & 0.20 & 0.04 & 0.26 \\
\hline
\end{tabular}

Table 12. Interaction effect of bentonite type and K-fertilizer level on some chemical contents of potato tuber (combined of two seasons)

\begin{tabular}{ccccccc}
\hline $\begin{array}{c}\text { Bentonite } \\
\text { type }\end{array}$ & $\begin{array}{c}\text { K-fertilizer } \\
(\mathbf{\%})\end{array}$ & $\begin{array}{c}\text { Starch } \\
\mathbf{( \% )}\end{array}$ & $\begin{array}{c}\text { Protein } \\
\mathbf{( \% )}\end{array}$ & $\begin{array}{c}\mathbf{N} \\
\mathbf{( \% )}\end{array}$ & $\begin{array}{c}\mathbf{P} \\
\mathbf{( \% )}\end{array}$ & $\begin{array}{c}\text { K } \\
(\mathbf{\%})\end{array}$ \\
\hline & $\mathbf{0}$ & 66.70 & 9.50 & 1.48 & 0.38 & 1.34 \\
$\mathbf{0}$ & $\mathbf{5 0}$ & 67.60 & 9.93 & 1.56 & 0.43 & 1.58 \\
& $\mathbf{7 5}$ & 70.90 & 10.70 & 1.71 & 0.42 & 1.72 \\
& $\mathbf{1 0 0}$ & 71.50 & 10.91 & 1.75 & 0.42 & 1.83 \\
$\mathbf{1 5}$ ton/fad. & $\mathbf{0}$ & 68.70 & 10.52 & 1.69 & 0.53 & 1.75 \\
black & $\mathbf{5 0}$ & 70.90 & 11.52 & 1.99 & 0.57 & 2.35 \\
& $\mathbf{7 5}$ & 73.80 & 12.61 & 1.97 & 0.57 & 2.43 \\
& $\mathbf{1 0 0}$ & 74.20 & 12.85 & 2.07 & 0.57 & 2.42 \\
$\mathbf{1 5}$ ton/fad. & $\mathbf{0}$ & 68.20 & 10.68 & 1.71 & 0.51 & 1.73 \\
brown & $\mathbf{5 0}$ & 70.50 & 11.75 & 1.55 & 0.53 & 2.12 \\
& $\mathbf{7 5}$ & 73.40 & 12.52 & 2.00 & 0.54 & 2.38 \\
LSD 5\% & $\mathbf{1 0 0}$ & 73.90 & 12.93 & 2.06 & 0.53 & 2.40 \\
\hline
\end{tabular}


$100 \mathrm{~kg} \mathrm{~K}_{2} \mathrm{O} / \mathrm{fad}$. The positive effects of bentonite in grown, yield and chemical composition of potatoes may be due to improving soil properties i.e., water holding capacity, field capacity and CEC which led to increase in various plant metabolites for cell division and elongation. Also, incorporation of bentonite in soil reduces leaching fertilizer wash off from sandy soil and increase available nutrients and reduces environmental pollution. Increasing nutrients in rooting caused an increase of its absorption by plants, consequently increased the ability of plants roots to uptake more elements in plant trusses.

\section{REFERENCES}

AOAC (1990). Official Methods of Analysis. $15^{\text {th }}$ Ed. Association of Official Analytical Chemist, Washington, DC, USA.

Chapman, H.D. and P.F. Pratt (1982). Methods of Analysis for Soils, Plants and Waters Chapman. Publishers, Riverside, Colifornia, USA.

Churchman, G.J., A.D. Noble and D.J. Chittleborough (2012). Addition of clay and clay minerals to enhance the sequestration of Carbon in soils. Australian Regaldth and clays Conference. Mildura. Aust., 117- 120

Cottenie, A., M. Verloo, G. Velghe and R. Cameriynck (1982). Chemical analysis of Plant and Soil. Lab. Anal. and Agrochem., State Univ., Ghent, Belgium.

Croker, J., R. Poss, C. Hartmann and J.S. Bhutharndhara (2004). Effect of recycled bentonite addition on soil properties, plant growth and nutrient uptake in a tropical sandy soil. Plant and Soil, 267: 155- 163.

Ding, S.L., Y.T. Sun, C.N. Yong and B.H. Xu (2009). Removal of copper from aqueous solution by bentonite and the factor affecting it. Min. Sci. Tech., 19 : 492- 499.

Imas, P. and S.K. Bansal (2002). Potassium and integrated nutrient management in potato. Global Research and Devlopment (Proceedings of the Global Confernce on potato, New Delhi, India Obell December (1999). Khurouna SME, Shekhawat G.S, Sing B.P and Fandey, Skced, 2: 744- 754.
Iskander, A.L., E.M. Khold and A.S. Sheta (2011). Zinc and manganese sorption behavior by natural Ziolte and bentonite. Ann. Agric. Sci., 36 : 43- 48.

Jena, D. and S. Kabi (2012). Effect of gromor sulphur, bentonite sulphur pastille or yield and nutrient uptake by hybrid nice- potato green gram cropping system in an incept sol. Int. Res. J. Agric. Sci. Soil Sci., 2 (5) : 179197.

Jones, C. and J.P. Jacobsen (2001). Plant nutrition and soil fertility. Nutrient Management Module No. 2 Moi taba 5 tat Univ., Extension Service PR11.

Jonusz, C. and S. Grzegorz (2013). Effect of bentoite on sandy soil chemistry in a longterm plot experiment (II), effect on $\mathrm{pH}$, CEC and Macro and micronutrients. Pol. J. Environ. Stud., 22 (6): 1667- 1676.

Lotfy, A.A. and O.A. El-Hady (1984). Effect of bentonite on some characters, yield and water use efficiency of kidny been in sandy soil under trick irrigation. Egypt J. Soil Sci., 24 (3): $225-340$

Marschner, H. (1995). Mineral Nutrition of Higher Plant. $2^{\text {nd }}$ Ed. Acad. (in Press) London, 234.

Marton, L. (2001). Potassium effects on potato (Solanm tuberoum L.) Yield. J. Potassium Res., 17 (44): 89-92.

Mohammed, V. and R.N. Mohammed (2012). The effect of various nitrogen fertilizer amount on yield and nitrate accumulation in tuber of two potato cultivars in cold regions of Isfhan (Iran). Int. J. Agric. Crop. Sci., 4 (22): 1682-1691.

Qu, G., A. Devarennes and C. Cunha-Queda (2008). Remediation and mince soil with insoluble polyacrylete polymers enhances soil quality and plant growth. Soil Use Manag., 24: 350-356.

Roberts, S. and R.E. Mc Dole (1985). Potassium nutrition of potatos. In Monson, RS (Ed.) Potassium Agric. ASA. CssA- SSSA, WI, $800-818$. 
Shaheen, A.M., F.A. Rizk and E.H. Abd ElSamad (2013). Effect of nitrogen fertilizer and soil conditioner on the productivity of potato plants grown under sandy soil conditions. J. Apl. Sci. Res., 9 (3): 17741781.

Satje, A. and P. Nelson (2009). Bentonite treatments can improve the nutrient and water holding capacity of sugarcane soils in the wet tropics Proc. Aust. Soc. Sugar cane Technol., 31: 166-176.

Shahzad, J., S.R.Z. Mohmoodabod and A. Yari (2010). Yield and yield compounds of potato (Solanum tuberosum L.) tuber as affected by nitrogen fertilizer and plant density. Aust. J. Basic. Appl. Sci., 9: 3129- 3131.

Singh, J.P. (1999). Potassium fertilization of potatos in north India. In proceeding of IPI Workshop on (essential role of potassium in diverse cropping system, held at the $16^{\text {th }}$ World Congress of Soil Sci. Monnte Peller France 20 - 26. August, 1998. Int. Potash Inst., Basel, Swizer Lend: 128- 129.

Singh, S.K. and S.S. Lai (2012). Effect of potassium nutrition on potato yield, quality and nutrient use efficiency under varied levels of nitrogen application. Potato. J., 39 (2): 155-165.
Soha, R., S.S. Mondel and J. Dos (2001). Effect of potassium with and without sulfure containing fertilization on growth and yield of potato (Solanum tuberosum L.). Enver. Ecol., 19 (1): 202- 205.

Snedecor, G.W. and W.G. Cochran (1990). Statistical Methods. $8^{\text {th }}$ Ed. Iowa State Univ., Press, Ames, Iowa.

Tawfiq, A.J. (2009). Improvement of sandy soil properties by using bentonite, K. Ufa. J. Eng., 1: 29- 39.

Umar, S. and D. Mairu (2001). Effect of sources and rates of potassium application on potato yield and economic neturn. Bette Crops Int., 15 (1): 13-15.

Upodhaya, N.C. and R.C. Sharma (1987). Variets differences in fertilizer use efficiency for nitrogen in potato. J. Indian Soil. Sci., 35 : 654- 660 .

Yssad, H.R. and M. Belkhodja (2007). The effect of bentonite on the physical-Chemical characteristics of sandy soils in Algeria. J. Appl. Sci., 7 : 2641 - 2645.

Zekri, M. and I.A. Obreza (2009). Plant nutrients fractures trees. SL, 200, UF/IFAS Ext. Serv., Inst. Food and Agric. Sci. Univ. Florida. 
تأثير إضافة نوعين من البونتيت على كفاءة التسميل البوتاسى وعلاقته بتحسين نمو محصول البطاطس

$$
\begin{aligned}
& \text { رمضان عبدالعاطى محمد' - محمد عبدالستار عبدالرحيم؟ - أنيس محمد ابراهيم؟ }
\end{aligned}
$$

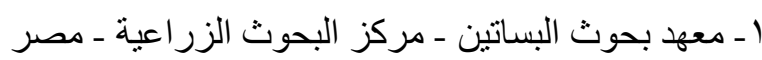

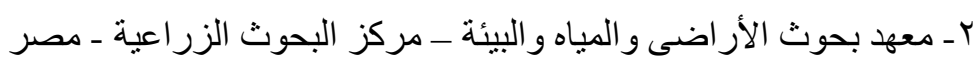

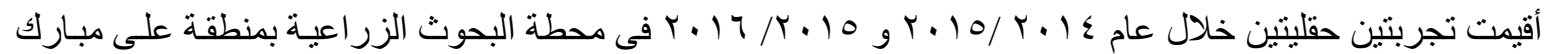

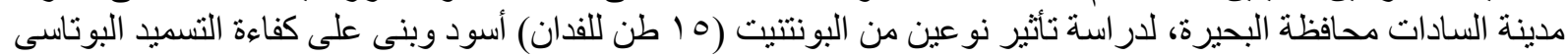

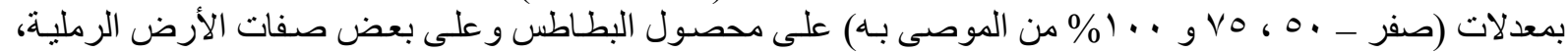

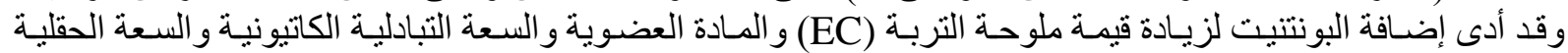

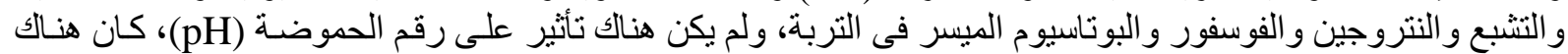

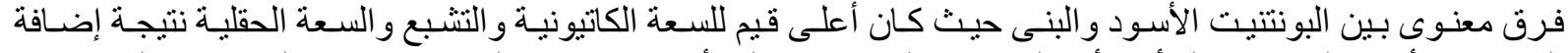

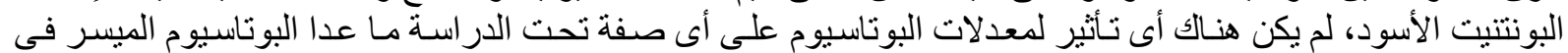

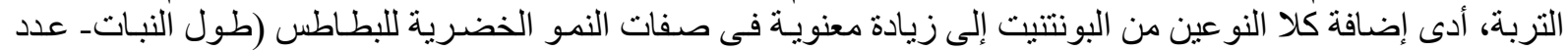

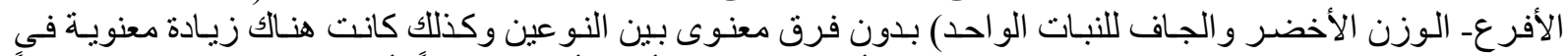

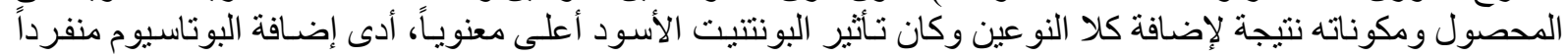

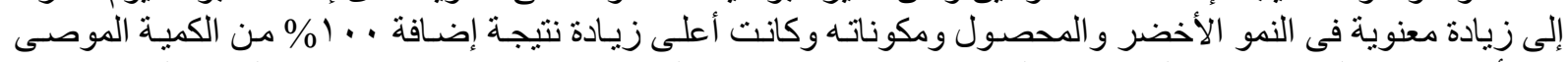

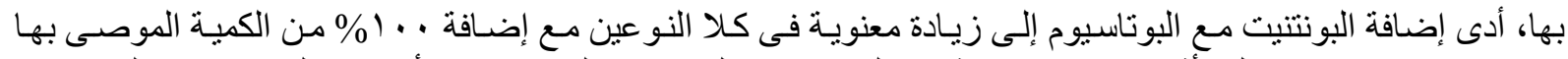

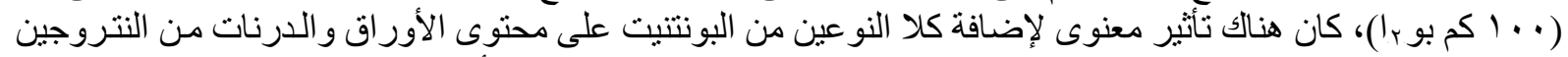

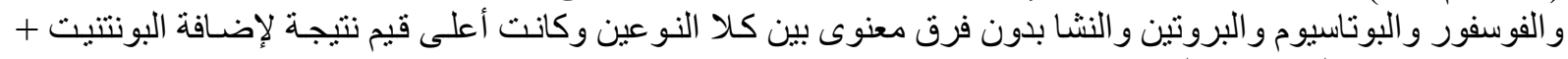
• . 1\% من كمية البوتاسيوم الموصى بو بها.

أستاذ الأراضي - مركز البحوث الزراعية.

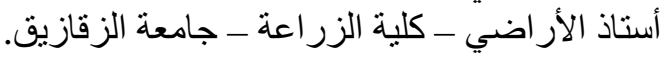

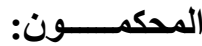

